\title{
Burke Marshall's Memorial
}

\author{
John Doar ${ }^{\dagger}$
}

This Tribute remembers and reflects upon the life of Burke Marshall, who began his public career in February 1961 as Assistant Attorney General, Civil Rights Division, Department of Justice.

Burke led the Division until January 1965. During that time, he guided the country from a segregated, second-class system for black citizens throughout the Solid South to the events at Selma in early 1965 that brought the country the Voting Rights Act of 1965.

In May 1961, Burke advised Attorney General Robert Kennedy and President John Kennedy during the constitutional crisis of the Freedom Rides in Montgomery, Alabama. Experience gained during that crisis led to the desegregation of interstate bus travel. Burke quickly came to understand better than anyone the complex legal and procedural problems caused when a state threatens to abandon its public safety responsibilities whenever black citizens attempt to exercise their constitutional rights.

During May, Burke recommended to the Attorney General that the Department file four voter discrimination suits in Mississippi. One of them was against Walthall County, a back-country county lying along the Mississippi-Louisiana border where there were no black citizens registered to vote.

In early July 1961, Bob Moses, a field secretary for the Student Nonviolent Coordinating Committee (SNCC), wrote a letter to Burke Marshall saying that his organization intended to operate in Mississippi, encouraging black citizens to register to vote. On July 13, the Attorney General sent Burke a handwritten note, which read: "What do you intend to do about Mississippi?""

$\dagger$ Assistant Attorney General, Civil Rights Division, U.S. Department of Justice, 1965-1967. This Tribute is an edited version of oral remarks given at a memorial service for Burke Marshall at the Yale Club of New York City on June 18, 2003.

1. Robert Kennedy's cryptic handwritten message to Burke Marshall was written on the "Remarks" portion of a Cover Memorandum from John Doar, Civil Rights Division, Department of Justice, to the Attorney General (July 10, 1961) (on file with author). 
On August 3, 1961, the Walthall voter discrimination suit was filed in the federal district court for the Southern District of Mississippi. On August 18, John Hardy, a black college student, opened a voter education school in Walthall County. Between August 30 and September 7, he brought eight black residents to the courthouse, but the Registrar of Voters refused to register any of them.

On Thursday, September 7, Hardy brought two elderly black residents to the courthouse. One of them told John Wood, the Registrar, that she had come to register to vote. Wood told her, "I am not registering anyone now. You all have got me in court and I refuse to register anyone else until this court [case] is cleared up."2 Hardy stepped forward and told Wood his name. Wood told Hardy he wanted to see him. Wood went to a desk and pulled out a gun, pointed it at Hardy, and told him to get out. As Hardy was leaving, Wood hit him on the head with the gun. Hardy, bleeding, stumbled outside and tried to find a law enforcement officer. Hardy met the sheriff in the street, but when he tried to make a complaint, the sheriff arrested him for disturbing the peace and put him in jail. ${ }^{3}$

When Burke learned what had happened, he immediately sent two Division lawyers to investigate. They were gone a week and returned on September 16 with statements of what had happened at the courthouse. They could not believe how bad the conditions were for black citizens along the Mississippi-Louisiana border. One of the lawyers made it clear that fear among the black: citizens and the intimidation and corruption among officials in Mississippi were so widespread that he believed it would take a commitment of enormous resources by the federal government even to scratch the surface in Mississippi. He questioned the willingness of the Kennedy Administration to commit such resources.

The following Monday, I called a meeting of the Division lawyers. As we reviewed what we had learned, Burke came in. He listened and was told that Hardy's trial for disturbing the peace was to occur the following Friday. In spite of the well-established rule that federal courts do not enjoin state criminal prosecutions, Burke immediately authorized the Division to seek to enjoin the case against Hardy. With that action, Burke gained the respect and admiration of every lawyer employed in the Division, and from that day on the Division lawyers went all out in enforcing the existing laws ensuring the right to vote.

We filed a complaint on Wednesday. On Thursday, Judge Harold Cox refused to stay the criminal case. Burke directed us to file a notice of appeal and to go to Judge Richard Rives of the U.S. Court of Appeals for the Fifth Circuit in Montgomery. Late that night, Judge Rives persuaded the State of

2. United States v. Wood, 295 F.2d 772, 776 (5th Cir. 1961).

3. See id. 
Mississippi to defer the criminal case until he could convene a three-judge court.

On October 3, Burke appeared before the court of appeals. He told the court that it "is justified in assuming that the false prosecution of one $[\mathrm{N}]$ egro, the first $[\mathrm{N}]$ egro who for many, many years had attempted to stir up registration activity in Walthall County... would adversely affect the registration activities in that county." He reminded the court that "these people live in an area where they are not used to the processes of the law, where there are virtually no lawyers who will help to protect them." ${ }^{5}$ The Fifth Circuit stayed the criminal prosecution, ${ }^{6}$ and the word went out that black citizens could rely on Burke Marshall.

In January 1962, the same court of appeals ordered University of Mississippi officials to admit James Meredith. Writing for the court, Judge Wisdom said: "A man should be able to find an education by taking the broad highway. He should not have to take by-roads through the woods and follow winding trails through sharp thickets ... and, after years of effort, perhaps attain the threshold of his goal when he is past caring ...."?

By August 1962, it looked to a lot of people-but not to Burke Marshall-that James Meredith was lost in a Mississippi thicket. In September, Burke, on behalf of the United States, moved the Fifth Circuit for an order allowing the United States to appear in the Meredith case. The motion was granted, and immediately thereafter a three-judge panel of the court of appeals - then sitting in Hattiesburg in a voter discrimination contempt case- - began to set aside the state court injunctions restraining Meredith from entering the University and enjoined the state courts from making findings that would render Meredith ineligible to attend.

On the same day, the University's board of trustees adopted a resolution appointing Governor Ross Barnett as Registrar. When Meredith tried to register, the governor rejected him.

On Monday, September 24, Chief Judge Tuttle convened an en banc hearing of the court of appeals in New Orleans on the ground that there had not been compliance with the court's earlier injunction. An array of Mississippi lawyers tried to dissuade the court from acting. But at the end of the day, the board of trustees agreed to comply with the order to admit Meredith. At the same time, the court enjoined Governor Barnett from interfering with that order. The next day, however, Governor Barnett again refused to register Meredith. On the following day, the lieutenant governor did the same.

4. Transcript of Oral Argument at 15, Wood (No. 19,237) (on file with author).

5. Id. at 16 .

6. For a recitation of the litigation's history, see United States v. Mississippi, 339 F.2d 679 (5th Cir. 1964).

7. Meredith v. Fair, 298 F.2d 696, 703 (5th Cir. 1962). 
On Friday, September 28, the court of appeals was back for a second en banc hearing. I wish you could have been there. There we were in the city of New Orleans in a magnificent courtroom before eight of the nine judges of the Court of Appeals for the old Fifth Circuit. Judge Tuttle presided. Alongside were Judges Hutcheson, Rives, Jones, Brown, Wisdom, Gewin, and Bell. Burke appeared for the United States.

Near the close of that second hearing, Chief Judge Tuttle spoke directly to Burke. Judge Tuttle made it clear that the court had exercised all the powers it possessed and he questioned Burke as to what the executive branch intended to do. Think of it: In a split second, without rehearsal, Burke was called upon to decide whether and how to commit the executive branch to an unequivocal course of action. At that point, Burke had to respond in a way that would best turn the State of Mississippi away from a course of actual insurrection. When Burke spoke, he was succinct, clear, and logical. His words reflected careful thought and extraordinary judgment.

In essence, Burke said to the court:

- the United States had a responsibility to make every effort to enforce the order of the court in a way least disruptive of the national interest;

- when dealing with a state, the United States wanted to give the state every opportunity to cooperate with the court and the federal government in seeing that the court's orders were obeyed;

- despite every attempt to persuade the State of Mississippi to respect and obey the court's order, so far the United States had failed and it appeared that stronger efforts would have to be made to enforce the order of the court;

- the order of the court would be enforced;

- there was no question that the executive branch would use whatever force-physical force, if that was required;

- it would take a good many law enforcement officials to make the order effective because Meredith not only had a right to be registered, but also had a right to remain a student; and

- the task would be easier and the country better off if the United States could bring Mississippi state officials and its governor to a 
recognition of their responsibilities to cooperate with instead of oppose the federal government. ${ }^{8}$

You all know what followed. In spite of considerable difficulty, but a lot less difficulty than would have occurred without Burke's firmness and judgment, Meredith was registered, enrolled, and attended the University of Mississippi, and the certainty of total racial segregation in public education in Mississippi was finally broken. Soon after that, Burke was in the middle of the Birmingham crisis, where the confidence and respect both sides had for Burke led to the beginning of a similarly successful outcome-the passage of the Civil Rights Act of 1964.

What do I believe was Burke's philosophy as he carried out his assignment as the head of the Civil Rights Division? No one could put it better than Burke himself when, in 1970, he reflected on why he had been such a strong advocate for the public accommodation section of the Civil Rights Act of 1964:

I always thought-and I know Bob Kennedy always thought, without, I think, any glimmer of a doubt-that just because of the trust, you know, the need to keep the Negroes believing in their government, we had to support them on that issue. At least morally, it was right ....",

From time to time, a young law student asks me whether he or she should work at the Department of Justice. "By all means," I say. But I also say, "Try to be there when the Attorney General is the brother of the President." I wish I could also say, "Be there when a Burke Marshall is in charge of the Civil Rights Division." But there is only going to be one Burke Marshall, and we who knew him know how lucky we were.

You know, this is something, really something. I am extolling the life of a man and he wasn't even a Supreme Court Justice, and after we are gone and when the books are written, he may or may not be in them. And yet, there was nobody more important than this quiet man to our history of racial justice.

8. For a verbatim transcription of Burke Marshall's remarks, see Transcript of Oral Argument at 77-80, Meredith v. Fair, No. 19,475 (5th Cir. argued Sept. 28, 1962) (en banc) (on file with author).

9. Interview by Larry J. Hackman with Burke Marshall, in Bedford, N.Y. (Jan. 19-20, 1970) (transcript on file with author). 


$$
* * *
$$

Imaged with the Permission of Yale Law Journal 